\title{
Construction of Full-length Dimer Clones of Yellow Mosaic Virus and Screening of Blackgram Germplasm using Agroinoculation
}

\author{
B.H. Chaithanya, B.V. Bhaskara Reddy, L. Prasanthi, R. Sarada Jayalakshmi Devi, \\ K. Manjula, G. Mohan Naidu
}

$10.18805 / L R-4775$

\begin{abstract}
Background: Vigna mungo (Blackgram) is the major pulse crop cultivated in the Indian sub-continent. It is highly prone to yellow mosaic disease (YMD), which is widespread problem because all cultivated varieties are susceptible to the YMD in Andhra Pradesh state. The presence of two species of begomovirus i.e. Mungbean yellow mosaic virus (MYMV) and Mungbean yellow mosaic India virus (MYMIV) with YMD was reported in Andhra Pradesh. The current study was aimed to develop simple method of viral dimer clone construction and identifying the resistant blackgram genotypes against two species of begomovirus (MYMV and MYMIV) by agroinoculation technique.

Methods: In this study, we standardize the rolling circle amplification (RCA) based viral dimer clone construction (MYMV DNA-A, MYMV DNA-B and MYMIV DNA-A) and constructed viral dimer clones were used to transform Agrobacterium tumefaciens EHA105 cells through freeze-thaw technique. Sprouted seed method of agroinoculation screening was conducted.

Result: Total 45 blackgram genotypes were screened by sprouted seed method of agroinoculation with two combinations of viral dimeric constructs (MYMV-TPT-A+MYMV-TPT-B and MYMIV-TPT-A+MYMV-TPT-B). Twenty four genotypes offered resistant against MYMV infection and twenty three genotypes were resistant to MYMIV infection. Total 17 genotypes offered resistance to both species of virus (MYMV andMYMIV) associated with YMD.
\end{abstract}

Key words: Agroinoculation, Blackgram, Mungbean yellow mosaic virus, Screening

\section{INTRODUCTION}

Blackgram [Vigna mungo (L.) Hepper] is the third major pulse crop of India and contributes $70 \%$ of the world's total blackgram production. The India, Black gram crop is cultivated in an area of 29.03 Mha with a total production of 23.4 Mt with a productivity of $806 \mathrm{~kg} / \mathrm{ha}$ during 2018-19 (Directorate of Economics and Statistics, 2019). Yellow mosaic disease (YMD) is the major constraint to the productivity of grain legumes across the Indian subcontinent and the estimated annual yield loss in three legumes i.e. Blackgram, Greengram and soyabean was \$300million (Varma and Malathi 2003). The reduction in seed yield was due to YMD in blackgram was $100 \%$ (Vadivel et al. 2021) and it was $20-70 \%$ in green gram (Ramarao et al. 2021). The YMD in southern Asia is caused by four distinct begomoviruses collectively known as the yellow mosaic viruses (YMVs): Mungbean yellow mosaic virus (MYMV), Mungbean yellow mosaic India virus (MYMIV), Dolichos yellow mosaic virus (DoYMV) and Horsegram yellow mosaic virus (HgYMV) (Qazi et al. 2007). Of these MYMIV and MYMV are most important as it infect a large number of legumes in India.

The existence of two species of begomoviruses (MYMIV and MYMV) with YMD of blackgram in Andhra Pradesh was reported (Reddy et al. 2014). The diverse virus isolates of MYMV have different levels of stability or virulence, as reflected by the symptom severity in each genotype of
Department of Plant Pathology, Regional Agricultural Research Station, Acharya N.G. Ranga Agricultural University, Tirupati517 502, Andhra Pradesh, India.

Corresponding Author: B.H. Chaithanya, Regional Agricultural Research Station, Acharya N.G. Ranga Agricultural University, Nandyal, Kurnool-522 007, Andhra Pradesh, India.

Email: chaitu453@gmail.com

How to cite this article: Chaithanya, B.H., Reddy, B.V.B., Prasanthi, L., Devi, R.S.J., Manjula, K. and Naidu, G.M. (2022). Construction of Full-length Dimer Clones of Yellow Mosaic Virus and Screening of Blackgram Germplasm using Agroinoculation. Legume Research. DOI: 10.18805/LR-4775.

Submitted: 24-08-2021 Accepted: 14-12-2021 Online: 18-01-2022

mungbean (Sathya et al. 2013). The concomitant existence of both species with YMD of blackgram results in the variation of symptoms in blackgram. As a result of this, each genotype exhibits a different level of resistance against diverse viral isolates and it is also difficult to confirm the resistance to which species of begomovirus under field conditions. Even the success of screening under field conditions for YMV resistance would depend upon the season, climate and vector population.

To accomplish this, it is necessary to establish a simple inoculation technique for the efficient evaluation of resistance against particular species of begomovirus. Here, we applied 
the rolling circle amplifica-tion ( $R C A$ ) method for the construction of infec-tious MYMV-TPT-A, MYMIV-TPT-A and MYMV-TPT-B dimer clones. This technique will allow screening germplasm throughout the year with various isolates/strains of virus which is not possible by natural field screening. The objective of this study was to develop a simple method of viral dimer clone construction and identify the resistant blackgram genotypes against two species of begomovirus (MYMV and MYMIV) by agroinoculation technique.

\section{MATERIALS AND METHODS Blackgram genotypes}

Total forty-five blackgram genotypes were collected from pulse breeder, Regional Agricultural Research Station, Tirupati. These genotypes were screened against MYMV and MYMIV through the agroinoculation technique during 2017-19. The details of blackgram genotypes are as follows.

\section{IVT entries}

COBG 13-04, GBG-12, LBG-888, ADBG-13023, COBG-653, TJU-258, OBG-38, TJU-103, OBG-39, DKU-95 and IPU 12-30.

\section{AVT entries}

NDUK 15-222, PU 13-15, RU 03-22, VBG 12-034, KPU $12-$ 213, VBG 12-111, TJU 24, DKU 82, MDBGV 06, KPU121730, KU 16-07, IPU 13-3, DKU 99, IPU 2-43, AKU 1316, PU 11-25, COBG 13-14, DKU 116 and KUG 718.

\section{Advanced breeding lines}

TBG-123 TBG-125 TBG-129 TBG138.

\section{Other genotypes}

ABG-1, ABG-3, PU-31, TBG-104, GBG-1, LBG-787, LBG752, LBG-623, LBG-645, PBG-1 and PBG-32.

\section{Construction of infectious MYMV and MYMIV dimer clones}

The rolling circle amplification (RCA) was done with blackgram genomic DNA isolated from the YMD infected samples from the Tirupati region (Packialakshmi et al. 2010). The viral dimers were generated by partial restriction digestion $(B a m \mathrm{HI})$ product of multimeric viral genomes produced by RCA with phi 29 DNA polymerase. The viral dimer clone construction (MYMV-TPT-A, MYMIV-TPT-B and MYMV-TPT-B) was standardized in our study and described in results and discussion part.

\section{Sprout- seed method of agroinoculation}

EHA 105 Agrobacterium cells harboring full-length dimers of MYMV DNA-A and MYMV DNA-B were grown to $O D_{600}$ of 0.8 and mixed in equal proportion. Bacterial cells were collected by low-speed centrifugation (5000RPM) and cells were resuspended in a small volume of Luria broth with $100 \mu \mathrm{m}$ acetosyringone and used for inoculation. Seeds of blackgram plants were surface sterilized and soaked in sterile water for 2-3hrs and kept for germination overnight at $37^{\circ} \mathrm{C}$, seed coat of sprouted seeds were removed by using forceps and pinpricked around the hypocotyls region with a fine needle and were immediately immersed in
Agrobacterium cells containing DNA-A of MYMV and DNA$B$ of MYMV. After $2 \mathrm{hrs}$ incubation seeds were washed and sown in pots. These pots were maintained in a plant growth chamber at $25 \pm 2^{\circ} \mathrm{C}, 60-70 \% \mathrm{RH}$ with a $16 \mathrm{hr}$ photoperiod (Jacob et al. 2003). The percent disease incidence was calculated and the presence of the virus associated with infected plants was confirmed by PCR.

\section{Polymerase chain reaction}

PCR was performed in $25 \mu \mathrm{l}$ reaction mixture containing $1 \mathrm{X}$ $\mathrm{PCR}$ reaction buffer, $2.5 \mathrm{mM} \mathrm{MgCl} 2,10 \mathrm{mM}$ each dNTPs, 10 pmoles of forward and reverse primer, $2.5 \mathrm{U} / \mu \mathrm{l} \mathrm{Taq}$ polymerase and $100 \mathrm{ng}$ of DNA template.The amplification of specific gene was performed in PCR machine. The PCR products were analyzed on $1 \%$ agarose gel electrophoresis.

\section{RESULTS AND DISCUSSION}

\section{Construction of full-length viral dimer clones}

In order to get dimer length fragment of the viral genome, the RCA product was partially digested with EcoRI/ HindIII/ BamHI restriction enzymes with three concentrations each $(0.1 \mathrm{U}, 0.2 \mathrm{U}$ and $0.3 \mathrm{U})$ at different incubation periods $(5 \mathrm{~min} /$ $10 \mathrm{~min} / 15 \mathrm{~min})$. Finally with repeated attempts, partial digestion of RCA product (dimer-2x) was yielded successfully with $0.2 \mathrm{U}$ of $\mathrm{BamH} 1$ restriction enzyme for $10 \mathrm{~min}$ of the incubation period. This dimer length $(5.9 \mathrm{~kb})$ fragment of the viral genome was eluted and ligated into a binary vector pCAMBIA 2301 at BamHI site (Fig 1). Ligated products were transformed into Escherichia coli (TOP 10) cells. Confirmation of recombinant clones was done by PCR using specific primers designed to DNA-A (Chattopadhyay et al. 2010; F- GGATCCATTGTTGAACGACTTTCC / RGGATCCCACATTGTT AGTGGGTTC) and DNA-B of begomoviruses (Naimuddin et al. 2011; F-ATGGAGAATT ATT CAGGCGCA/ R-TTACAACGCTTTGTTCACATT) and further confirmation was done by restriction digestion analysis with two combinations of restriction enzymes (HindIII / Sacl and Pst1/ EcoRI). In our study total of three dimer clones were constructed (MYMV-TPT-A, MYMIV-TPTA and MYMV-TPT-B) in the PCAMBIA 2301 vector (Fig 2).

\section{Infectivity analysis of constructed viral clones}

To test the infectivity, MYMV-TPT-A, MYMIV-TPT-A and MYMV-TPT-B dimer clones were introduced into competent

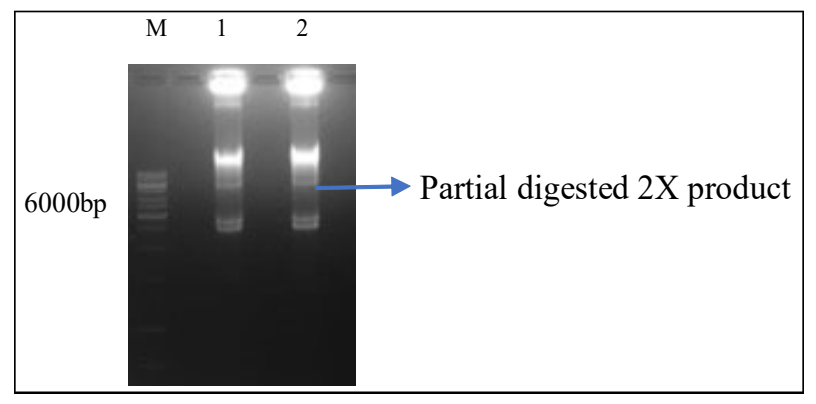

Fig 1: Partial digestion of RCA product with BamH1 (0.2U) for 10 min. Lane M:1Kb ladder (SMO313) Lane 1 and 2: RCA product. 


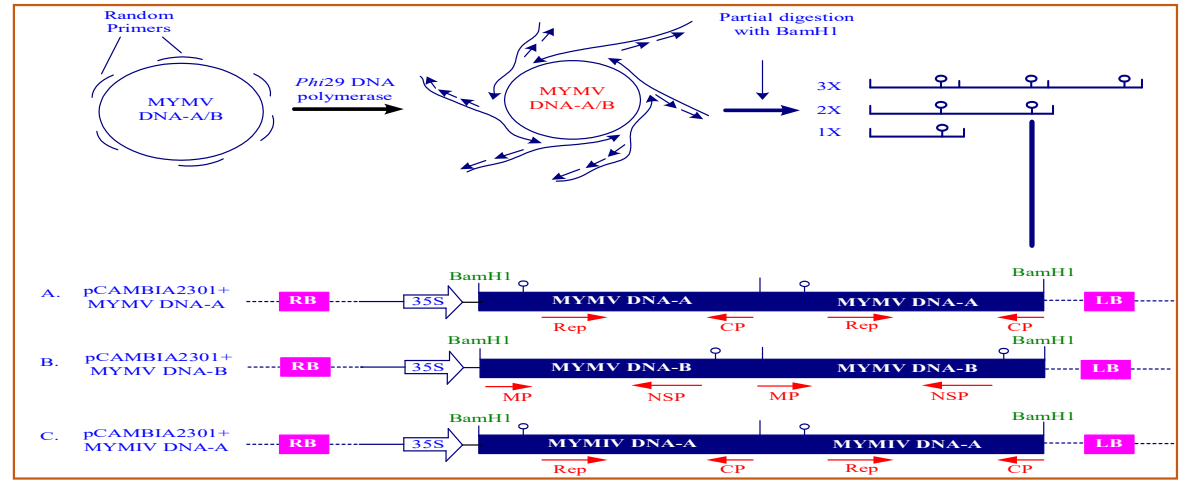

Fig 2: Linear map of dimeric constructs of MYMV DNA-A (A); MYMV DNA-B (B) and MYMIV DNA-A(C).

Table 1: Infectivity response of blackgram susceptible variety to agroinoculation.

\begin{tabular}{lccc}
\hline Experiment details & $\begin{array}{c}\text { Total no of } \\
\text { agroinoculated } \\
\text { seeds sown }\end{array}$ & $\begin{array}{c}\text { Total no of plants which } \\
\text { shown characteristic } \\
\text { YMD symptoms }\end{array}$ & $\begin{array}{c}\text { Per cent of infectivity } \\
\text { by agroinoculation } \\
(\%)\end{array}$ \\
\hline Agroinoculation with MYMV-TPT-A and MYMV-TPT-B & 20 & 18 & 90 \\
Agroinoculation with MYMIV-TPT-A and MYMV-TPT-B & 20 & 19 & 95 \\
\hline
\end{tabular}

cells of Agrobacterium tumefa-ciens (EHA 105) by freezethaw method. The pres-ence of the binary vector in $A$. tumefaciens was confirmed by PCR using specific primers and restriction digestion analysis.

To confirm the infectivity/ to prove Koch's postulates for constructed dimer clones, agroinoculation was done in two sets using known susceptible genotype PBG-32. One set of agroinoculation was carried out using Agrobacterium strains containing MYMV-TPT-A andMYMV-TPT-B dimeric clones and the second set of agroinoculation was done with Agrobacterium strains containing MYMIV-TPT-A andMYMVTPT-B dimeric clones. In two experiments, we observed characteristic yellow mosaic symptoms on first emerged trifoliate at 8-12 days after inoculation (DAI). It was confirmed that both DNA-A components (MYMV and MYMIV) are infectious when agroinoculated with one DNA-B component (MYMV) and successfully express the viral genome in the blackgram plant.

The genotypes were observed up to 25-30 days for symptoms expression and percentage incidence of disease was recorded (Table 1). The accumulation of virus was detected by PCR using coat proteinand movement protein specific primers.

In the PCR analysis, virus presence was observed in symptomatic and asymptomatic agroinoculated plants as well as in a few control plants. The differences in band intensity were observed between symptomatic, asymptomatic agroinoculated and control blackgram plants. It is necessary to investigate the fate of the virus in asymptomatic and control plants as there was no symptoms were observed in the total growth period of blackgram plants. It was reported that the presence of MYMV in various parts of blackgram seed like seed coat, cotyledon and embryonic axis was confirmed by different techniques like PCR, southern blot analysis and sequencing. When the growing test was performed with same batch seeds, no symptom development was reported in the seedlings. These results indicate the seed borne nature of the MYMV and it was hypothesized that the robust metabolic environment of a growing seedling may not be favourable to efficient build-up and translocation of the virus (Kothandaraman et al. 2016). But in greengram, seed borne nature of YMD was contradicted by naimuddin et al. 2016. Thus, detailed analysis is still needed to confirm the exact mechanism of the seed-borne nature of YMVs in different Vigna species (Mishra et al.2020). The concentration of virus particles needed for symptom expression in blackgram should be analyzed. Similarly, the relation between virus load and resistance level in plants is to be studied.

Most of the infectious clones of begomovirus were constructed by inserting a fragment containing intergenic region into the end of full-length genome (partial tandem repeat) which usually involve the selection and design of cloning sites, and several subcloning procedures, which is a laborious process. Recently, rolling circle amplification (RCA) technology has been developed for amplification of any circular DNA for research and diagnostic purpose without using PCR. This method generates tandemly repeated conctamers/ viral multimers and partial digestion of these viral multimers with restriction enzymes will generate infectious dimers that can clone into any plant transformation vector without any further sub cloning procedures (InoueNagata et al. 2004).

Several workers were made infectious partial dimeric clones of geminivirus by RCA method (Balaji et al. 2004; Bag et al. 2014; Karthikeyan et al. 2004 and Jacob et al. 2003). In this study, we successfully generated infectious full dimeric clones (MYMV-TPT-A, MYMIV-TPT-A and MYMV- 
TPT-B) and further used in the screening experiment. Similarly, infectious complete tandem dimeric construct of Chickpea chlorotic dwarf Pakistan virus associated with chickpea stunt disease was constructed by kanakala et al., 2013.

Total of 45 genotypes were screened by the sprouted seed method of agroinoculation. The screening experiment was carried out separately with two combinations of viral clones (MYMV-TPT-A+MYMV-TPT-B and MYMIV-TPT$A+M Y M V-T P T-B)$ to know the resistant response of blackgram genotypes against MYMV and MYMIV infection. The disease rating scale 0-9 was used to categorize the genotypes (Sudha et al. 2013).
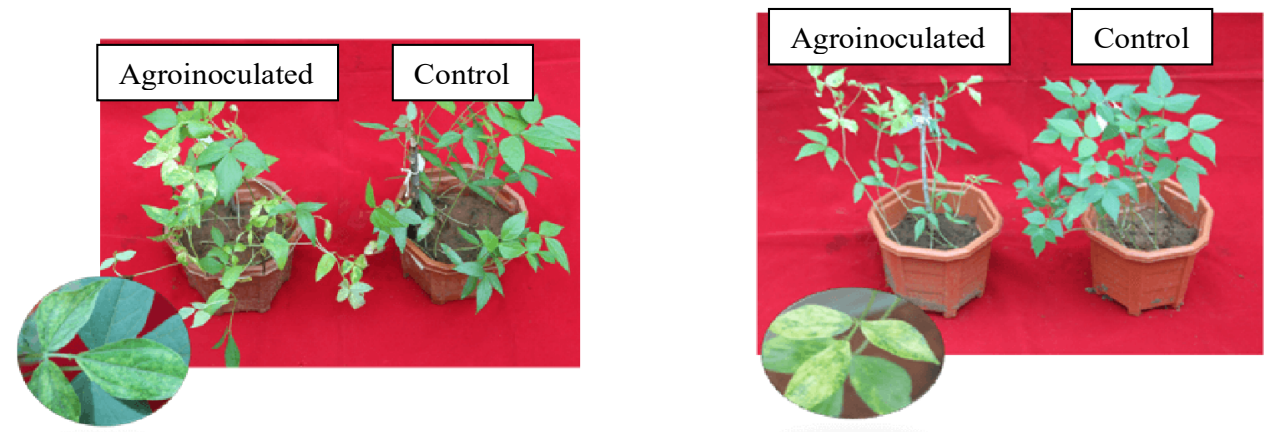

(a) Highly susceptible reaction of blackgram genotypes (DKU-99and PU 11-25) in agroinoculation with MYMIV-TPT-A + MYMV-TPT-B.
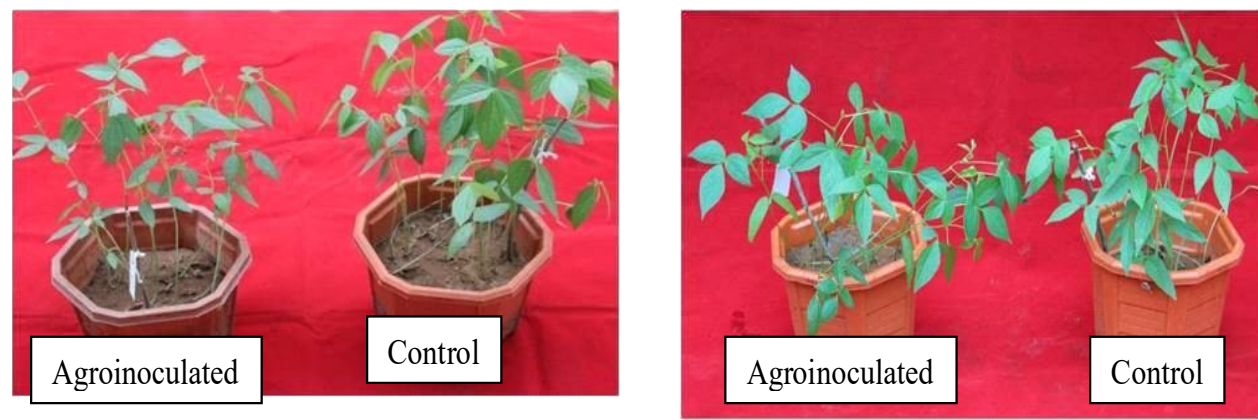

(b) Resistant reaction of DKU-99 and PU 11-25genotypes in agroinoculation with MYMV-TPT-A + MYMV-TPT-B.
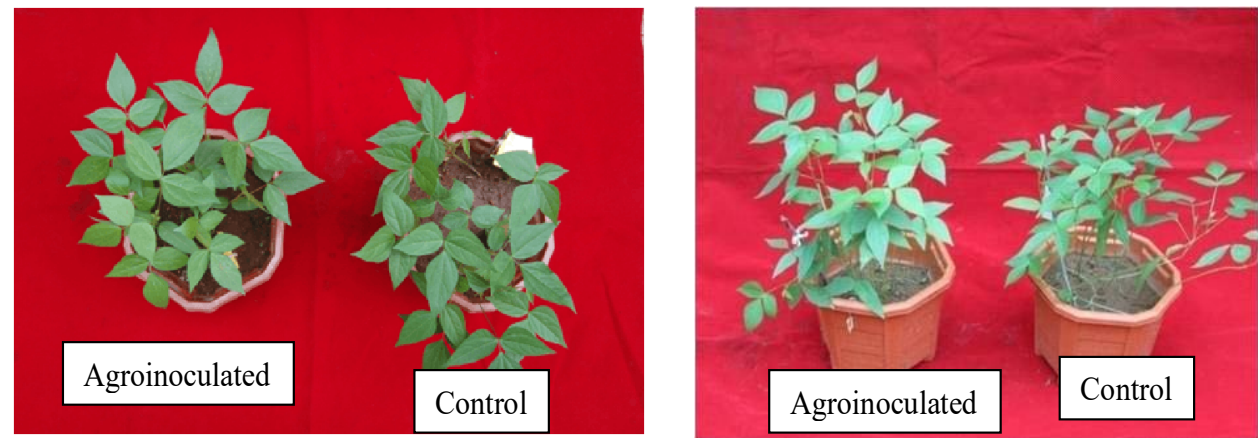

(c) Resistant reaction of CO 13-14 and LBG-888 genotypes in agroinoculation with MYMIV-TPT-A + MYMV-TPT-B.
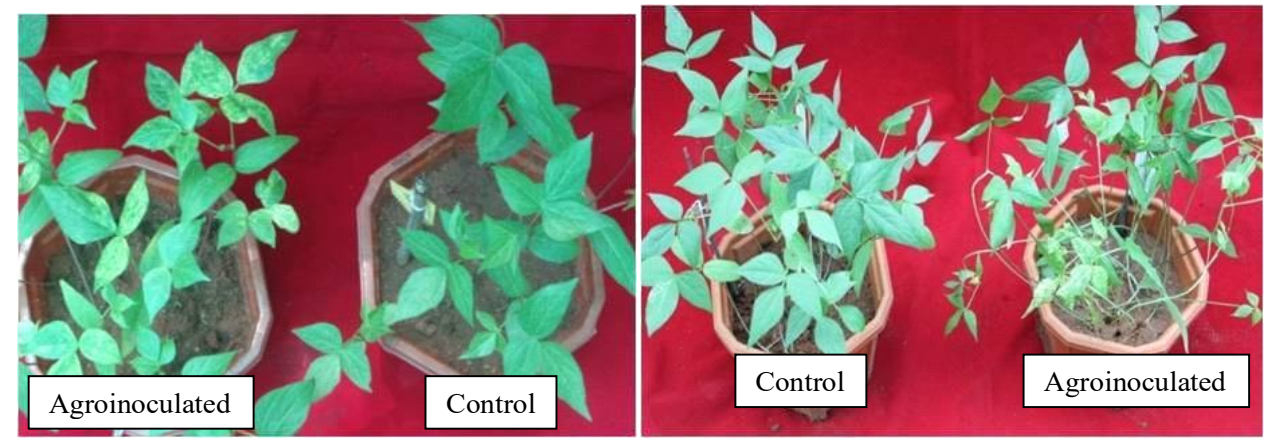

(d) Susceptible reaction of CO 13-14 and LBG-888 genotypes in agroinoculation with MYMV-TPT-A + MYMV-TPT-B.

Fig 3 (a-d): Differential response of the blackgram genotypes to agroinoculation with respective DNA-A of MYMV and MYMIV. 
Table 2: Disease response of blackgram genotypes to agroinoculation.

\begin{tabular}{|c|c|c|c|c|c|c|}
\hline \multirow[b]{2}{*}{ Genotype } & \multicolumn{2}{|c|}{ Mean percent disease incidence } & \multicolumn{2}{|c|}{ Disease scale } & \multicolumn{2}{|c|}{ No. of days for symptom development } \\
\hline & $\begin{array}{l}{ }^{\text {st }} \text { screening } \\
\text { experiment }(\mathrm{I})\end{array}$ & $\begin{array}{l}\mathrm{II}^{\text {nd }} \text { screening } \\
\text { experiment (II) }\end{array}$ & 1 & II & 1 & II \\
\hline NDUK 15-222 & - & - & 1 & 1 & $\mathrm{NI}$ & $\mathrm{NI}$ \\
\hline PU 13-15 & - & - & 1 & 1 & $\mathrm{NI}$ & $\mathrm{NI}$ \\
\hline RU 03-22 & 14.6(MS) & $23.85(S)$ & 5 & 5 & 12 & 14 \\
\hline VBG 12-034 & 14(MS) & - & 5 & 1 & 17 & $\mathrm{NI}$ \\
\hline KPU 12-213 & - & - & 1 & 1 & $\mathrm{NI}$ & $\mathrm{NI}$ \\
\hline VBG 12-111 & - & - & 1 & 1 & $\mathrm{NI}$ & $\mathrm{NI}$ \\
\hline TJU 24 & - & - & 1 & 1 & $\mathrm{NI}$ & $\mathrm{NI}$ \\
\hline DKU 82 & 4.35(MR) & - & 3 & 1 & 23 & $\mathrm{NI}$ \\
\hline MDBGV 06 & 16(MS) & $23.45(\mathrm{~S})$ & 5 & 5 & 17 & 12 \\
\hline KPU12-1730 & - & - & 1 & 1 & $\mathrm{NI}$ & $\mathrm{NI}$ \\
\hline KU 16-07 & - & - & 1 & 1 & $\mathrm{NI}$ & $\mathrm{NI}$ \\
\hline IPU 13-3 & - & - & 1 & 1 & $\mathrm{NI}$ & $\mathrm{NI}$ \\
\hline DKU 99 & - & $100(\mathrm{HS})$ & 1 & 9 & $\mathrm{NI}$ & 17 \\
\hline IPU 2-43 & $6.25(\mathrm{MR})$ & - & 3 & 1 & 17 & $\mathrm{NI}$ \\
\hline AKU 1316 & 4.25(MR) & 83.65(HS) & 3 & 9 & 17 & 14 \\
\hline PU 11-25 & - & $59.15(\mathrm{HS})$ & 1 & 9 & $\mathrm{NI}$ & 14 \\
\hline COBG 13-14 & $26.5(\mathrm{~S})$ & - & 7 & 1 & 23 & $\mathrm{NI}$ \\
\hline DKU 116 & - & - & 1 & 1 & $\mathrm{NI}$ & $\mathrm{NI}$ \\
\hline KUG 718 & - & - & 1 & 1 & $\mathrm{NI}$ & $\mathrm{NI}$ \\
\hline COBG 13-04 & $35.4(\mathrm{~S})$ & $27.05(S)$ & 7 & 7 & 16 & 17 \\
\hline GBG-12 & $27.05(S)$ & $52.05(\mathrm{HS})$ & 7 & 9 & 19 & 17 \\
\hline LBG-888 & $23.9(\mathrm{~S})$ & - & 7 & 1 & 22 & $\mathrm{NI}$ \\
\hline ADBG-13023 & $41.3(\mathrm{~S})$ & $63.7(\mathrm{HS})$ & 7 & 9 & 16 & 17 \\
\hline COBG-653 & 79.15(HS) & 72.95(HS) & 9 & 9 & 16 & 19 \\
\hline TJU-258 & 57.15(HS) & $55.5(\mathrm{HS})$ & 9 & 9 & 16 & 20 \\
\hline OBG-38 & - & $42.8(\mathrm{~S})$ & 1 & 7 & $\mathrm{NI}$ & 24 \\
\hline TJU-103 & - & $15.15(\mathrm{MS})$ & 1 & 5 & $\mathrm{NI}$ & 22 \\
\hline OBG-39 & $15.85(\mathrm{MS})$ & $65.9(\mathrm{HS})$ & 5 & 9 & 19 & 24 \\
\hline DKU-95 & - & 36.75(HS) & 1 & 5 & $\mathrm{NI}$ & 20 \\
\hline IPU 12-30 & - & - & 1 & 1 & $\mathrm{NI}$ & $\mathrm{NI}$ \\
\hline TBG138 & - & - & 1 & 1 & $\mathrm{NI}$ & $\mathrm{NI}$ \\
\hline PU-31 & - & - & 1 & 1 & $\mathrm{NI}$ & $\mathrm{NI}$ \\
\hline TBG-104 & - & - & 1 & 1 & $\mathrm{NI}$ & $\mathrm{NI}$ \\
\hline GBG-1 & - & - & 1 & 1 & $\mathrm{NI}$ & $\mathrm{NI}$ \\
\hline LBG-787 & - & $12.25(\mathrm{MS})$ & 1 & 5 & $\mathrm{NI}$ & 16 \\
\hline ABG-1 & 4.25(MR) & $25.55(\mathrm{~S})$ & 3 & 7 & 22 & 24 \\
\hline ABG-3 & - & 19.1(MS) & 1 & 5 & $\mathrm{NI}$ & 24 \\
\hline TBG-123 & $14.55(\mathrm{MS})$ & - & 5 & 1 & 22 & $\mathrm{NI}$ \\
\hline TBG-129 & - & - & 1 & 1 & $\mathrm{NI}$ & $\mathrm{NI}$ \\
\hline TBG-125 & - & - & 1 & 1 & $\mathrm{NI}$ & $\mathrm{NI}$ \\
\hline LBG-645 & 79.6(HS) & $85.4(\mathrm{HS})$ & 9 & 9 & 14 & 15 \\
\hline LBG-623 & $80.9(\mathrm{HS})$ & $100(\mathrm{HS})$ & 9 & 9 & 16 & 15 \\
\hline LBG-752 & 64.6(HS) & $100(\mathrm{HS})$ & 9 & 9 & 15 & 17 \\
\hline PBG-1 & $85.4(\mathrm{HS})$ & $100(\mathrm{HS})$ & 9 & 9 & 9 & 10 \\
\hline PBG-32 & 89.8(HS) & 89.45(HS) & 9 & 9 & 10 & 12 \\
\hline
\end{tabular}

Note: $\left.\right|^{\text {st }}$ Screening experiment: Agroinoculation with MYMV-TPT-A+MYMV-TPT-B.

$I^{\text {nd }}$ Screnning experiment: Agroinoculation with MYMIV-TPT-A+MYMV-TPT-B.

R-Resistant, MR-Moderately resistant, MS- Moderately susceptible, S-Susceptible, H-Highly susceptible and NI-No Infection. 
Total of 45 blackgram genotypes were subjected to agroinoculation in two replications with two combinations of viral clones. The agroinoculated blackgram genotypes started showing characteristic yellow mosaic symptoms from 8-25 days of agroinoculation and no symptoms were observed in control plants. The average percent infection of agroinoculated blackgram genotypes ranged between 0$100 \%$. The genotypes from each category (S, HS, MS, MR and $\mathrm{R}$ ) or disease response of each genotype are given in Table 2. It was observed that, among 45 genotypes, 24 genotypes offered resistance against MYMV infection and 23 genotypes were resistant to MYMIV infection. On the $25^{\text {th }}$ day, diseased leaf samples were collected for DNA isolation. The isolated DNA samples were analyzed for the presence of viral genome by PCR by coat protein and movement protein specific primers. As described earlier, presence of viral genome was noticed even in a few control plants.

Interestingly, thirteen genotypes namely VBG 12-034, DKU 82, DKU 99, IPU 2-43, PU 11-25, COBG 13-14, LBG888, OBG-38, DKU-95, TJU 103, ABG-1, ABG-3 and TBG123 showed differential resistant response to agroinoculation with respective DNA-A of MYMV and MYMIV. Among thirteen genotypes, DKU 99 and PU11-25 genotypes were resistant to MYMV infection, but they were highly susceptible to MYMIV infection (Fig 3a-b).Whereas COBG 13-14 and LBG 888 genotypes were susceptible to MYMV infection and showed resistance to MYMIV infection (Fig 3c-d). Finally,17 genotypes i.e. NDUK 15-222, PU 13-15, KPU 12-213, VBG 12-111, TJU 24, KPU12-1730, KU 1607, IPU 13-3, DKU 116, KUG 718, IPU 12-30, TBG-138, PU-31, TBG-104, GBG-1,TBG-129 and TBG-125 offered resistance to both species of virus (MYMV andMYMIV). Among these 17 genotypes, TBG 129 and TBG-125 are advanced breeding germplasm developed from RARS, Tirupati. To confirm the results the experiment had repeated once and comparable results were observed. The above results clearly indicated that there is a differential resistant response of genotypes against MYMV and MYMIV infection was noticed. The sequence information of constructed clones might give a clue for this differential resistance response of the genotypes.

A Similar type of artificial screening of germplasm by agroinoculation technique was previously done in different hosts like blackgram, greengram, soyabean and cowpea by several workers (Jacob et al. 2003; Usharani et al. 2004; Karthikeyan et al. 2011; Sudha et al. 2013; Bag et al. 2014; Madhumitha et al. 2020), But all these screening trials were evaluated with DNA-A and DNA-B clones of MYMV. In this study, first time we attempted the screening experiment with clones of MYMIVDNA-A and MYMVDNA-B along with MYMV DNA-A and DNA-B clones.

\section{ACKNOWLEDGEMENT}

This study was supported by a grant from the RKVY project and the Authors wish to thank the Associate Director of
Research, Regional Research Station, Tirupati for providing infrastructural support at Institute of Frontier Technology, RARS, Tirupati.

\section{REFERENCES}

Bag, M.K., Gautam, N.K., Prasad, T.V, Pandey, S., Dutta, M., Roy, A. (2014). Evaluation of an Indian collection of blackgram germplasm and identification of resistance sources to Mungbean yellow mosaic virus. Crop Protection. 61: 92-101.

Balaji, V., Vanitharani, R., Karthikeyan, A.S., Anbalagan, S., Veluthambi, K. (2004). Infectivity analysis of two variable DNA B components of mungbean yellow mosaic virus-Vigna in Vigna mungo and Vigna radiata. Journal of Bioscience. 29(3): 297-308.

Chattopadhyay, D., Yadavkumar, R., Shuklakumar, R. (2010). Chimeric construct of mungbean yellow mosaic India virus (MYMIV) and its uses thereof. Pub. No: US 2010/0285445 A1.

Directorate of Economics and Statistics, (2019). Agricultural Statistics at a Glance, Ministry of Agriculture and farmers welfare, Government of India, New Delhi (http://https:// eands.dacnet.nic.in/PDF/At\%20a\%20Glance\%202019 $\% 20$ Eng.pdf).

Nagata, A.K., Albuquerque, L.C., Rocha, W.B., Nagata, T. (2004). A simple method for cloning the complete begomovirus genome using the bacteriophase phi29 DNA polymerase. Journal of Virological Methods. 116(2): 209-211.

Jacob, S.S., Vanitharani, R., Karthikeyan, A., S., Chinchore, Y., Thillaichidambaram, P. and Veluthambi, K. (2003). Mungbean yellowmosaic virus-Vi agroinfection by codelivery of DNA A and DNA B from one Agrobacterium strain. Plant Disease. 87: $247-25$.

Kanakala, S., Sakhare, A., Verma, H.N., Malathi, V.G. (2012). Infectivity and the phylogenetic relationship of a mastrevirus causing chickpea stunt disease in India. Eur. J. Plant Pathol. 135: 429-438.

Kanakala, S., Sakhare, A., Verma, H.N., Malathi, V.G. (2012). Infectivity and the phylogenetic relationship of a mastrevirus causing chickpea stunt disease in India. Eur. J. Plant Pathol. 135: 429-438.

Kanakala, S., Sakhare, A., Verma, H.N. and Malathi, V.G. (2013). Infectivity and phylogenetic relationship of a mastrevirus causing Chickpea stunt disease in India. European Journal of Plant Pathology. 135 (2): 429-438.

Karthikeyan, A.S., Vanitharani, R., Balaji, V., Anuradha, S., Thillai-chidambaram, P., Shivaprasad, P.V., Parameswari, C., Balamani, V., Saminathan, M., Veluthambi, K. (2004). Analysis of an isolate of Mungbean yellow mosaic virus (MYMV) with a highly variable DNA-B component. Archives of Virology. 149: 1643-1652.

Karthikeyan, A.S., Sudha, M., Pandiyan, M., Senthil, N., Shobana, V.G. and Nagarajan, P. (2011). Screening of MYMV resistant mungbean [Vigna radiate (L.) Wilczek] progenies through Agroinoculation. International Journal of Plant Pathology. 2(3): 115-125.

Kothandaraman, S.V., Devadason, A. and Ganesan, M.V. (2016). Seed-borne nature of a begomovirus, Mungbean yellow mosaic virus in Blackgram. Applied Microbiogy and Bioechnology. 100-1925-1933. 
Madhumitha, B., Aiyanathan, K.E.A., Raveendran, M. and Sudha, M. (2020). Identification and confirmation of resistance in mungbean [Vigna radiata (L.) Wilczek] derivatives to mungbean yellow mosaic virus (MYMV). Legume Research. DOI: $10.18805 / L R-4437$.

Mishra, G.P., Dikshit, H.K., Ramesh, S.V., Tripathi, K., Kumar, R.R., Aski, M., Singh, A., Roy, P., Kumari, N., Dasguptha, U., Kumar, A., Praveen, S., Nair, R.M. (2020). Yellow mosaic disease (YMD) of mungbean [Vigna radiata (L.) Wilczek], current status and management opportunities. Frontiers in Plant Science. 11: 918. doi: 10.3389/fpls.2020.00918.

Naimuddin, K., Akram, M., Pratap, A. (2011). First report of natural infection of mungbean yellow mosaic india virus in two wild species of Vigna. New Disease Reports. 23: 21.

Naimuddin, K., Akram, M., Singh, N.P. (2016). Yellow mosaic of mungbean and urdbean: Current status and future strategies. Journal of Food Legumes. 29(2): 77-93.

Packialakshmi, R.M., Srivastava, N., Girish, K.R., Usha, R. (2010). Molecular characterization of a distinct begomovirus species from Vernonia cinerea and its associated DNAbeta using the bacteriophage Phi 29 DNA polymerase. Virus Genes. 41: 135-143.

Qazi, J., Iyas, M., Mansoor, S., Briddon, R.W. (2007). Legume yellow mosaic viruses: Genetically isolated begomoviruses. Molecular Plant Pathology. 8: 343-348.

Ramarao, G., Satishbabu, J., Haarisatyanarayana, N. and Adinarayana, M. (2021). Morho-physiological and biochemical variability in Grengram [Vigna radiate (L.) Wilczek] arieties for mungbean yellow mosaic virus (MYMV) Resistanceunder naturalfield conditions. Legume Research. DOI: 10.188 05/LR-4534.
Reddy, B.V.B., Obaiah, S., Prasanthi, L., Sivaprasad, Y., Sujitha, A., Giridhara Krishna, T. (2014). Mungbean yellow mosaic India virus is associated with yellow mosaic disease of blackgram (Vigna mungo L.) in Andhra Pradesh, India. Archives of Phytopathology and Plant Protection. 1-11.

Satya, V.K., Malathi, V.G., Velazhahan, R., Rabindran, R., Jayamani, P., Alice, D. (2013). Characterization of betasatellite associated with the yellow mosaic disease of grain legumes in Southern India. Acta Virologica. 57(4): 405-414.

Sudha, M., Karthikeyan, A., Nagarajan, P., Raveendran, M., Senthil, N., Pandiyan, M., Angappan, K., Ramalingam, J., Bharathi, M., Rabindran, R., Veluthambi, K. (2013). Screening of mungbean (Vigna radiata) germplasm for resistance to Mungbean yellow mosaic virus using Agroinoculation. Candian Journal of Plant Pathology. 35(3): 424-430.

Usharani, K.S., Surendranath, B., Haq, Q.M.R., Malathi, V.G. (2004). Yellow mosaic virus infecting soybean in Northern India is distinct from the species infecting soybean in Southern and Western India. Current Science. 86: 845-850.

Vadivel, K., Manivannan, N., Mahalingam, A., Satya, V.K. Vanniarajan, C. and Ragul, S. (2021). Identification and validation of quantitative trait loci of Mungbean yellow mosaic virus disease resistance in Blackgram [Vigna mungo (L). Hepper]. Legume Research. DOI:10.18805/LR-4459.

Varma, A., Malathi, V.G. (2003). Emerging geminivirus problems: A serious threat to crop production. Annal of Applied Biology. 142: 145-164. 